\title{
Novel genotype of Ehrlichia canis detected in samples of human blood bank donors in Costa Rica
}

\author{
Laura Bouza-Mora ${ }^{a}$, Gaby Dolz $^{\mathrm{a}, *}$, Antony Solórzano-Morales ${ }^{\mathrm{a}}$, Juan José Romero-Zuñiga ${ }^{\mathrm{a}}$ \\ , Lizbeth Salazar-Sánchez ${ }^{\mathrm{b}}$, Marcelo B. Labruna ${ }^{\mathrm{c}}$, Daniel M. Aguiar ${ }^{\mathrm{d}}$ \\ a Escuela de Medicina Veterinaria, Universidad Nacional, Campus Benjamín Nuñez, Barreal de Heredia, Heredia, Costa Rica

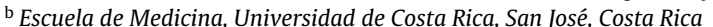 \\ c Faculdade de Medicina Veterinária e Zootecnia, Universidade de São Paulo, São Paulo, Brazil \\ d Faculdade de Medicina Veterinária, Universidade Federal de Mato Grosso Mato Grosso, Brazil
}

\section{A R T I C L E I N F O}

\section{Article history:}

Received 24 May 2016

Received in revised form 22 September 2016

Accepted 22 September 2016

Available online $\mathrm{xxx}$

\section{Keywords:}

Zoonosis

Bacteria

Ticks

Public health

\begin{abstract}
A B S T R A C T
This study focuses on the detection and identification of DNA and antibodies to Ehrlichia spp. in samples of blood bank donors in Costa Rica using molecular and serological techniques. Presence of Ehrlichia canis was determined in 10 (3.6\%) out of 280 blood samples using polymerase chain reaction (PCR) targeting the ehrlichial $d s b$ conserved gene. Analysis of the ehrlichial trp36 polymorphic gene in these 10 samples revealed substantial polymorphism among the $E$. canis genotypes, including divergent tandem repeat sequences. Nucleotide sequences of $d s b$ and trp36 amplicons revealed a novel genotype of $E$. canis in blood bank donors from Costa Rica. Indirect immunofluorescence assay (IFA) detected antibodies in 35 (35\%) of 100 serum samples evaluated. Thirty samples showed low endpoint titers (64-256) to E. canis, whereas five sera yielded high endpoint titers (1024-8192); these five samples were also E. canis-PCR positive. These findings represent the first report of the presence of E. canis in humans in Central America. (c) 2016 Elsevier GmbH. All rights reserved.
\end{abstract}

\section{Introduction}

Human ehrlichiosis are tick-borne zoonosis caused by rickettsial pathogens (order Rickettsiales, family Anaplasmataceae, genus Ehrlichia), considered as emerging pathogens in the United States, and increasingly, in many countries around the world (Ismail et al., 2010). Ehrlichia chaffeensis, the causative agent of human monocytic ehrlichiosis, is the most important species to infect humans, and less commonly, Ehrichia ewingii (human ewingii ehrlichiosis) (Dumler, 2005). The distribution of these diseases are largely determined by the presence of known competent tick vectors (Amblyomma americanum, the lone star tick) and reservoir hosts (Odocoileus virginianus, white-tailed deer) (Dumler, 2005). Although these agents may also affect dogs, canine monocytic ehrlichiosis, caused by Ehrlichia canis, is best recognized as a canine

\footnotetext{
* Corresponding author at: Escuela de Medicina Veterinaria, Universida Nacional, P.O. Box 86-3000, Heredia, Costa Rica.

E-mail addresses: laura.bouza.mora@una.cr (L. Bouza-Mora), gaby.dolz.wiedner@una.cr(G. Dolz), antony.solorzano.morales@una.cr (A. Solórzano-Morales), juan.romero.zuniga@una.cr (J.J. Romero-Zuñiga), lizbeth.salazar@gmail.com (L. Salazar-Sánchez), labruna@usp.br (M.B. Labruna), danmoura@ufmt.br (D.M. Aguiar).
}

pathogen, which is transmitted mainly by the brown dog tick, Rhipicephalus sanguineus sensu lato (s.l.) (Dawson et al., 1993; Dumler et al., 2001).

Until recently, E. canis was thought to infect only canines; however, it was isolated and molecularly characterized from an asymptomatic human in Venezuela (Perez et al., 1996), although its role as a pathogen was not immediately recognized. In 2006, E. canis was detected in human patients showing clinical findings compatible with ehrlichiosis (Pérez et al., 2006). Since then, E. canis should be considered as a potential agent of human illnesses in areas endemic for canine monocytic ehrlichiosis, caused by E. canis (Diniz et al., 2007; Nicholson et al., 2010).

Once the ehrlichial organisms are introduced into the host, they multiply in monocytes and macrophages (E. chaffeensis and E. canis) or in peripheral blood neutrophils (E. ewingii), and spread to phagocyte cells of different organs such as liver, spleen, lungs and lymph nodes (Dumler et al., 2001). Detection of morulae-like forms of Ehrlichia within leukocytes through stained blood smears lead to rapid diagnosis of Ehrlichia spp.; however, this detection method is usually efficient only during the initial stages of infection, when there are higher levels of rickettsemia (Chapman et al., 2006). In vitro isolation of viable ehrlichial organisms in cell culture remains the gold standard diagnostic method; however, it is time consuming and requires more refined laboratory conditions 
(Dawson et al., 1991; Felek et al., 2001; Gusa et al., 2001). Indeed, the most common diagnostic methods of rickettsial diseases, including ehrlichiosis, rely on serological and molecular assays (Chapman et al., 2006). While the indirect immunofluorescence assay (IFA) is frequently employed in research studies, this serologic method does not allow a precise identification of the Ehlichia species that caused infection, since there are serological cross-reactions, for example, between E. canis, E. chaffeensis and E. ewingii. In addition, serology does not allow determining whether the infection is active or occurred in the past (Breitschwerdt et al., 1998). Molecular tests such as polymerase chain reaction (PCR) lead to rapid and accurate diagnosis, determining the Ehrlichia species that could be actively infecting the host (Romero et al., 2010).

Ehrlichia canis was firstly reported infecting dogs in Costa Rica in 1995 (Meneses 1995). Since then, several studies have provided molecular detection of E. canis in blood samples of domestic and wild animals and their ticks in the country (Barrantes-González et al., 2016; Campos-Calderón et al., 2016; Dolz et al., 2015; Rojas et al., 2014; Romero et al., 2011). In the past, four clinical cases of ehrlichiosis were reported in humans in Costa Rica, based on clinical evaluation and microscopic detection of intracytoplasmic inclusions in granulocytes (Hernández de Mezerville and Padilla-Cuadra, 2007; Rojas-Solano and Villalobos-Vindas, 2007) and monocytes (Brenes et al., 2011) in peripheral blood. Recently, Rojas et al. (2015) reported human natural infection by E. chaffeensis in patients in the Northern region of Costa Rica. In the present work, we present evidence of Ehrlichia infection in blood bank donors, including the first report of a novel genotype of $E$. canis associated with humans in Costa Rica.

\section{Material and methods}

\subsection{Population studied}

Blood samples from blood bank donors collected during 2007 were analyzed by PCR targeting ehrlichial DNA. In addition, 100 serum samples, randomly selected from the same bank donor population, were tested by IFA for the presence of $E$. canis-reactive antibodies. The minimum sample size for detecting infection with an expected prevalence of $1 \%$ ( $95 \%$ confidence) in a population of 10,000 donors was 294. For logistics reasons the number of samples analyzed by PCR was 280 , which allows detecting a $1.1 \%$ infection prevalence.

According to universal criteria defined by Costa Rican blood banks, blood donors were 18-60 years old, weighed more than $50 \mathrm{~kg}$, and presented hemoglobin $>12 \mathrm{~g} / \mathrm{dl}$, hematocrit $>38 \%$, systolic arterial pressure $<160 \mathrm{mmHg}$ and diastolic arterial pressure $<100 \mathrm{mmHg}$. In addition, each blood sample was accompanied by sex and age of the donor.

\subsection{Polymerase chain reaction (PCR) and DNA sequencing}

Extraction of DNA from blood samples was carried out using the saline extraction method described by Miller et al. (1998). For molecular diagnosis, PCR was carried out to amplify a fragment of disulfide oxidoreductase gene $(d s b)$ of Ehrlichia spp. (Ndip et al., 2005) using the primers Dsb-330 (5'-GAT GAT GTC TGA AGA TAT GAA ACA AAT- $\left.3^{\prime}\right)$ and Dsb-728 (5'-CTG CTC GTC TAT TTT ACT TCT TAA AGT-3'). Each reaction consisted of $12.5 \mu$ l of Dream Taq ${ }^{\mathrm{TM}}$ PCR Master Mix 2X (Fermentas $\left.{ }^{\circledR}\right), 1.0 \mu \mathrm{l}$ of each primer $(10 \mathrm{pmol} / \mu \mathrm{l})$, $5 \mu \mathrm{l}$ of DNA (20 ng) and $5.5 \mu \mathrm{l}$ of water (molecular biology grade, Fermentas ${ }^{\circledR}$ ) in a final volume of $25 \mu$ l. Amplification was carried out by denaturalization at $95^{\circ} \mathrm{C}$ for $2 \mathrm{~min}, 40$ cycles of denaturalization $\left(30 \mathrm{~s}, 95^{\circ} \mathrm{C}\right)$, annealing $\left(30 \mathrm{~s}, 58^{\circ} \mathrm{C}\right)$, extension $\left(30 \mathrm{~s}, 72^{\circ} \mathrm{C}\right)$, and a final extension at $72{ }^{\circ} \mathrm{C}$ for $5 \mathrm{~min}$. Genomic DNA of $E$. canis
(KU534872) from a Rhipicephalus sanguineus s.l. tick from Costa Rica (Campos-Calderón et al., 2016), and E. chaffeensis and E. ewingii plasmids (Sirigireddy and Ganta, 2005) were used as positive controls; nuclease free water (Fermentas ${ }^{\circledR}$ ) was used as a negative control. The products obtained in PCR were visualized by $2 \%$ agarose gel Tris-Borate-EDTA electrophoresis, stained with DNA GelRed $\left(\right.$ Biotium $^{\circledR}$ ). Thermo Scientific GeneRuler 100 bp Plus DNA Ladder (Sm0321) molecular weight marker was included. Samples yielding visible PCR products compatible with 409 bp were considered positive for Ehrlichia sp.

Samples positive by the $d s b$-PCR assay were tested by a heminested PCR targeting a segment of the Tandem Repeat Protein 36 gene (trp36). In the first reaction, primers TRP36-F2 (5'-TTTAAAACAAAATTAACACACTA-3') and TRP36-R1 (5'AAGATTAACTTAATACTCAATATTACT-3) were used (Aguiar et al., 2013). Each reaction consisted of $12.5 \mu$ l of Dream Taq ${ }^{\mathrm{TM}}$ PCR Master Mix 2X (Fermentas $\left.{ }^{\circledR}\right), 3.0 \mu \mathrm{l}$ of each primer $(10 \mathrm{pmol} / \mu \mathrm{l})$, $4 \mu \mathrm{l}$ of DNA (20 ng) and $2.5 \mu \mathrm{l}$ of water (molecular biology grade, Fermentas ${ }^{\circledR}$ ) in a final volume of $25 \mu$ l. Amplification was carried out by denaturation at $95^{\circ} \mathrm{C}$ for $5 \mathrm{~min}, 35$ cycles of denaturation $\left(30 \mathrm{~s}, 95^{\circ} \mathrm{C}\right)$, annealing $\left(30 \mathrm{~s}, 52^{\circ} \mathrm{C}\right)$, extension $\left(1 \mathrm{~min}, 72^{\circ} \mathrm{C}\right)$, and a final extension of $72^{\circ} \mathrm{C}$ for $5 \mathrm{~min}$. In the nested reaction TRP36-R1 and TRP36-D_F (5'-CACACTAAAATGTATAATAAAGC-3') were used (Aguiar et al., 2014), with the same conditions as described above, but changing annealing temperature $\left(57^{\circ} \mathrm{C}\right)$. PCR products were visualized in $2 \%$ agarose gel Tris-Borate-EDTA electrophoresis, stained with DNA GelRed (Biotium ${ }^{\circledR}$ ). Thermo Scientific GeneRuler 100 bp Plus DNA Ladder (Sm0321) molecular weight marker was included. Samples yielding PCR products corresponding to $1000 \mathrm{bp}$ (first reaction) and $600 \mathrm{bp}$ (nested reaction) were considered positive for Ehrlichia sp.

PCR products were purified using the QIAquick ${ }^{\circledR}$ kit (QIAGEN), and sent to Macrogen (Seoul, Korea) for DNA sequencing. Partial sequences were aligned with BioEdit Sequence Aligment Editor ${ }^{\circledR}$ (Hall, 1999) and compared using the BLASTn algorithm with the database of NCBI (National Center for Biotechnology Information).

\subsection{Indirect immunofluorescence assay (IFA)}

Anti-Ehrlichia spp. antibodies were evaluated by IFA according to Aguiar et al. (2007), using Ehrlichia canis São Paulo isolate as antigen. Anti-human IgG secondary antibody (Caltag Laboratories) was used at the 1:200 dilution. A positive control serum was obtained from an experimentally infected dog, as well as a negative control serum from an uninfected dog (Aguiar et al., 2007). Reactive sera at the serum dilution 1:64 were considered seropositive, and subjected again to IFA testing with 2-fold serial dilutions in PBS, from $1: 64$ to $1: 8192$, to determine the final endpoint titer.

\subsection{Statistical analysis}

The frequencies of positive results by PCR and IFA tests were compared by using the Fisher's exact or chi-square test. They were also analyzed in $2 \times 2$ tables in the Egret epidemiological program version 2.0.3 (Cytel Software Corp.) to evaluate the epidemiological association of the presence of $E$. canis DNA or E. canis-reactive antibodies with donor sex or age. For PCR results, the variable "age" was classified by mean (younger or older than 29 years), median (younger or older than 27 years), and three specific arbitrary age strata ( $<25$, between 26 and 35 , and $>36$ years old).

\section{Results}

Among 280 blood analyzed samples, 10 (3.6\%) yielded amplicons of the expected size by the $d s b$ PCR. DNA sequences generated from these amplicons exhibited high identity with corresponding $E$. 
canis (AF403710). Sequences of samples 5, 7, 9, 13, 15 were identical to each other (base sequence CR1) and 100\% (400/400 bp) identical to E. canis (AF403710), while samples 1, 2, 3, 4 and 10 were identical to each other (base sequence CR2) and presented $99 \%$ (397/401 bp) of identity to the E. canis sequence (AF403710) available in GenBank. Deduced amino acid sequence from partial $d s b$ sequence was $99.2 \%$ (131/132 bp) similar to each other and $99.2 \%$ and $100 \%$ identical to E. canis (Genbank AF403710). Sequences of $d s b$ gene generated in this study (CR1, CR2) were deposited in GenBank accession number KR732921 and KR732922, respectively.

The trp36 gene was partially amplified (528-757 bp) and sequenced from four samples (1, 3, 5 and 7$)$. Sequences were identical to each other and the identities obtained were $98.7 \%$ (221/224 bp) similar to different strains of E. canis from Brazil (JX429924, JX312082, JX312080, JX312079, JX312081), and 95.7\% (200/209bp) with strains from Africa (JN982341, JN982338, JN622143, DQ146155) and Middle East (EU118961, EF636663). According to the amino acid sequence, the $\mathrm{N}$-termini region was $97.8 \%$ (89/91) identical to a strain from Brazil classified as the Brazilian genotype (GenBank AFS49963, AFS49962, AFS49965, AFS49964, AFT92033). A new tandem repeat sequence was observed, consisting of four repetitions of 'EASVVPAAEAPQPAQQTEDEFFSDGIEA' followed by a fifth sequence with the amino acids 'EASVVPAAEAPQPAQQTEDEFFSDGIE'. Interestingly, the first six amino acids are similar to the Brazilian genotype 'ASVVPEAE'. This last repetition sequence presented a deletion of Alanine in the last position before a new $\mathrm{C}$-termini region sequence with amino acid sequence of 'EVLSAFL'. A phylogenetic tree (Fig. 1) of E. canis TRP36 was performed with sequences of this study, and sequences available in GenBank. The Costa Rican amino acid sequence grouped in a clade with the Brazilian genogroup, previously detected in Brazilian dogs. Sequence of TRP36 gene generated in this study was deposited in GenBank under accession number KU194227.

Statistical association was not found when age was classified by median (27 years). However, when age was classified by the mean (29 years), donors $>29$ years old had 5.6 times more risk to have E. canis-PCR positive results than donors $\leq 29$ years old ( $\mathrm{p}=0.006$; IC 95\%: 1.3-28.3). In the arbitrary age stratification, there were no strata with statistically significant risks; however, an infection tendency risk was observed as age increased (Table 1). Overall, $45.3 \%$ (127/280) blood samples were from males, from which six were PCR-positive. Females were represented by 153 samples, with four PCR-positive. Statistical analysis did not show association between PCR results and age or sex $(\mathrm{p}=0.52)$.

Among 100 serum samples analyzed by IFA, 35 were reactive to E. canis antigens. Thirty of them presented relatively low endpoint titers (64-256), while five showed high endpoint titers (1024-8192); these five samples also showed PCR positive results. Among seropositive samples, 11 were from male donors, all <36 years old; 24 were female donors, mostly $(23 / 24)<36$ years old.

When the results of PCR and IFA obtained from the 100 human donors were compared, 64 showed negative results in both techniques, while 30 were IFA positive (titers ranging from 64 to 256) and PCR negative; five donors were IFA (titers from 1024 to 8192) and PCR positive. Only one donor was PCR positive and IFA nega-

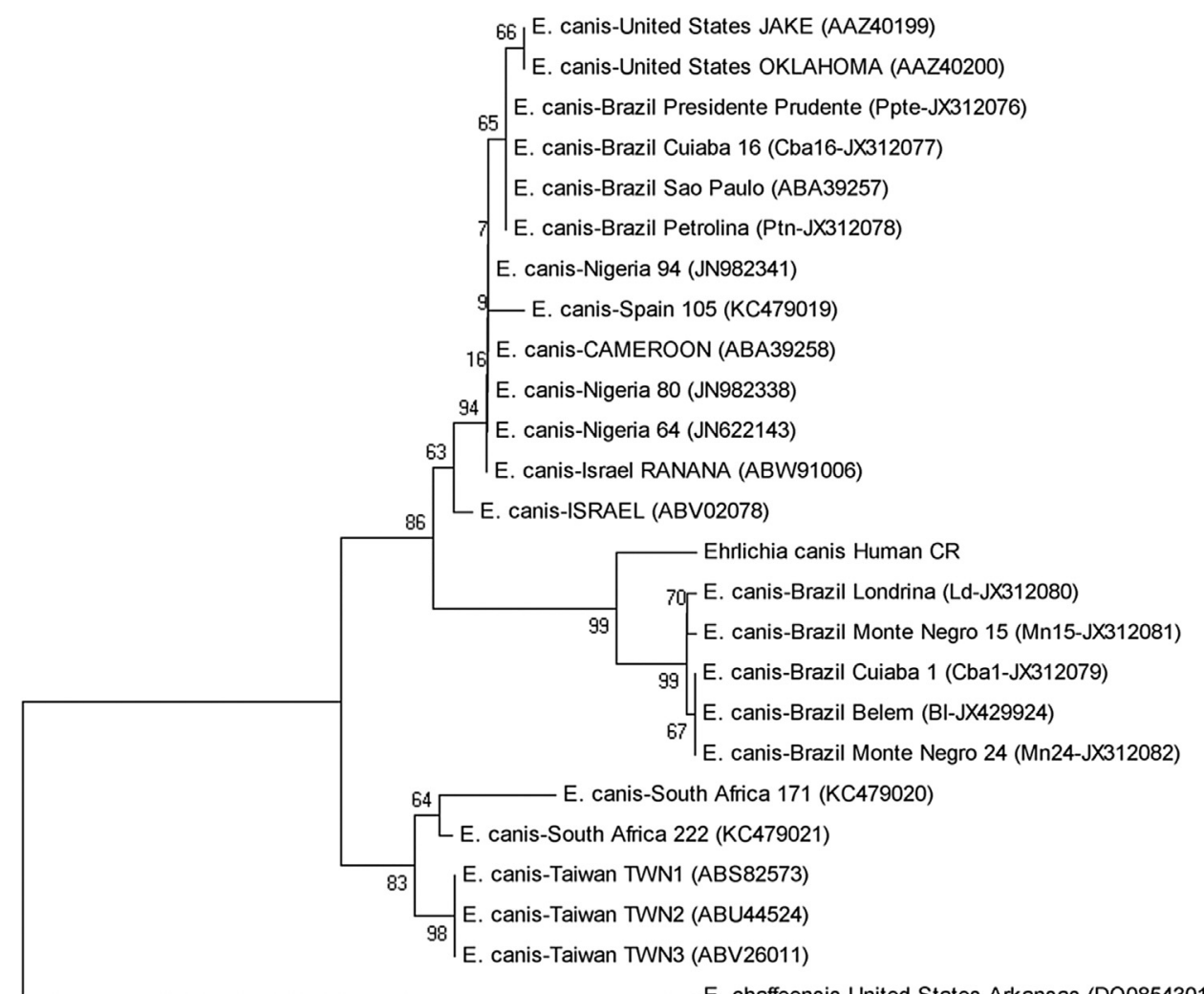

E. chaffeensis-United States Arkansas (DQ0854301)

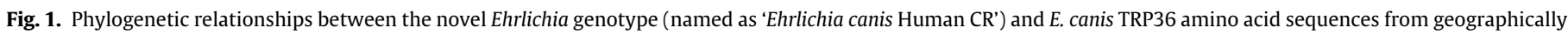

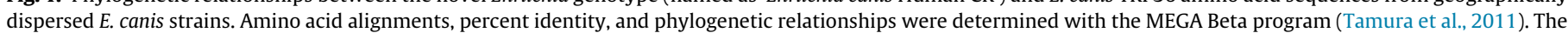

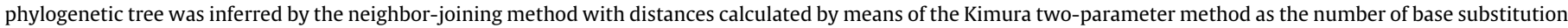

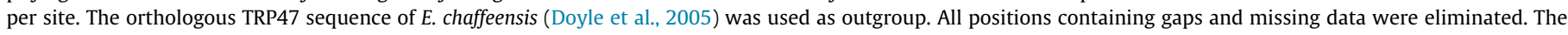
numbers at the nodes represent the percentage of 1000 bootstrap resamplings. 
Table 1

Distribution of PCR results by age, stratified by median, mean and arbitrary stratification defined by the researchers.

\begin{tabular}{lllll}
\hline Age $^{1}$ (years) & Positive & Total & OR & IC (95\%) \\
\hline$\leq 27$ & $3(2.0 \%)^{\mathrm{a}}$ & 150 & & \\
$>27$ & $7(5.4 \%)^{\mathrm{a}}$ & 130 & 2.8 & $0.63-13.90$ \\
Age $^{2}$ & Positive & Total & & \\
$\leq 29$ & $3(1.6 \%)^{\mathrm{a}}$ & 194 & & \\
$>29$ & $7(8.1 \%)^{\mathrm{b}}$ & 86 & 5.6 & $1.30-28.30$ \\
Age $^{3}$ & Positive & Total & & \\
$\leq 25$ & $2(1.9 \%)^{\mathrm{a}}$ & 101 & & \\
$26-35$ & $5(3.5 \%)^{\mathrm{a}}$ & 144 & 1.78 & $0.34-9.36$ \\
$\geq 36$ & $3(8.6 \%)^{\mathrm{a}}$ & 35 & 4.64 & $0.74-29.02$ \\
\hline
\end{tabular}

Proportions bearing different superscript letters differ significantly $(p<0.05)$.

1 Age classified in two strata according to the median.

2 Age classified in two strata according to the arithmetic median.

3 Age classified in three strata according to arbitrary criteria of the researchers.

tive; the remaining four PCR positive samples were not analyzed by IFA because they were not selected in the sub-sample due to budget reasons.

\section{Discussion}

Molecular detection and identification of E. canis in blood bank donors of Costa Rica is reported for the first time. Similarly to previous studies with canine or tick samples from Costa Rica (Barrantes-González et al., 2016; Campos-Calderón et al., 2016; Dolz et al., 2015; Rojas et al., 2014; Romero et al., 2011), we did not detect E. chaffeensis or E. ewingii DNA. While there is a single report of molecular diagnosis of E. chaffeensis in human patients in the Northern zone of Costa Rica (Rojas et al., 2015), our results indicate E. canis as the most prevalent Ehrlichia species infecting humans in the Country, similarly to the reports on animals (BarrantesGonzález et al., 2016; Campos-Calderón et al., 2016; Dolz et al., 2015; Meneses, 1995; Rojas et al., 2014; Romero et al., 2011). Human infection by E. canis in the present study was confirmed by molecular analysis of genes encoding two different proteins; $d s b$ a conservative protein that has been used to distinguish different species of Ehrlichia, and TRP36, a major immunoreactive protein useful for genotyping $E$. canis strains based on differences in tandem repeat number or sequences (Aguiar et al., 2013). Our analysis of later gene indicate that human ehrlichiosis in Costa Rica could be associated to a novel genotype of $E$. canis based on the amino acid tandem repeat sequence of the TRP36 protein. The N-termini sequence of $E$. canis from our TRP36 protein showed 98\% similarity to different Brazilian strains and this level of similarity is higher than observed against strains from Brazil and USA (Aguiar et al., 2013). Moreover, a novel amino acid sequence was observed in the repetition region of the protein. Phylogenetic tree inferred with TRP36 sequences generated in the present study showed that $E$. canis genotype detected in humans in Costa Rica grouped within a single clade closely related to the Brazilian genogroup, with high bootstrap support (99\%).

Human infection by E. canis has been reported in Venezuela and Mexico (Perez et al., 1996; Silva et al., 2014). The presence of $E$. canis in human blood samples in Costa Rica may be a result of the high prevalence of the agent in canines and their ticks (BarrantesGonzález et al., 2016; Campos-Calderón et al., 2016; Romero et al., 2010, 2011), which increases the likelihood of human exposure to infected ticks. In this context, tick control on dogs is critical to prevent human infection (Barrantes-González et al., 2016). Although $R$. sanguineus s.l. is a typical dog parasite, human parasitism by this tick group has been occasionally reported in many parts of the world, including Latin America (Goddard, 1989; Serra-Freire et al., 2011; Dantas-Torres et al., 2005, 2006; Guglielmone et al., 2006).
Interestingly, results of our serological analysis suggest that a high level (30\%) of blood donors seemed to have had contact in the past with $E$. canis, although cross-reactions with $E$. chaffeensis or other Ehrlichia species cannot be ruled out (Breitschwerdt et al., 1998). Considering the health status of blood donors in the present study, their likely infection by $E$. canis seemed to occur without disease. This could be due to low virulence of $E$. canis strains circulating in the country, or to the presence of diseases with similar pathologies in the country, which evolve with nonspecific clinical signs, and therefore goes undiagnosed (Perez et al., 1996).

Finally, a tendency towards risk of infection was observed as age increases, which is consistent with Pérez et al. (2006), who reported that higher the age, the greater the probability of having been in contact with an infected tick. The foregoing allows us to raise some important questions: could it be that canine ehrlichiosis, so common in our environment, is responsible for the fact that in Costa Rica human beings are exposed and generate antibodies without this leading to persons contracting the disease? How important are persistent infections in humans? Will they trigger chronic diseases? How important is it that blood with E. canis be transfused to diseased or inmunosuppressed persons? Who are the persons most likely to suffer an E. canis infection? Further clinical and epidemiological studies are recommened to find answers to all these questions.

\section{Conclusions}

This study reports the presence of $E$. canis, and specific antibodies against this agent, in the blood of blood bank donors in Costa Rica, which provides the first confirmed diagnosis of $E$. canis in humans in Central America. An increased risk of infection with increased age was found in the studied group of blood donors.

\section{Acknowledgments}

This investigation was supported by the Fondo Especial para el Financiamiento de la Educación Superior, Consejo Nacional de Rectores (FEES-CONARE), by the Vicerrectoría de Investigación, Universidad Nacional, and received support from the "Red Iberoamericana de Investigación y Control de Enfermedades Rickettsiales" (RIICER-CYTED). We thank the Conselho Nacional de Desenvolvimento Científico e Tecnológico of Brazil (CNPq) for the for Scientific Productivity Grant to M.B. Labruna and D.M. Aguiar.

\section{References}

Aguiar, D.M., Saito, T.B., Hagiwara, M.K., Machado, R.M., Labruna, M.B., 2007. Diagnóstico sorológico de erliquiose canina com antígeno brasileiro de Ehrlichia canis [Serological diagnosis of canine ehrlichiosis with Brazilian E. canis antigen]. Cienc. Rural 37, 796-802.

Aguiar, D.M., Zhang, X., Melo, A.L.T., Pacheco, T.A., Meneses, A.M., Zanutto, M.S. Horta, M.C., Santarém, V.A., Camargo, L.M., McBride, J.W., Labruna, M.B., 2013. Genetic diversity of Ehrlichia canis in Brazil. Vet. Microbiol. 164, 315-321.

Aguiar, D.M., Ziliani, T.F., Zhang, X., Melo, A.L., Braga, I.A., Witter, R., et al., 2014. A novel Ehrlichia genotype strain distinguished by the TRP36 gene naturally infects cattle in Brazil and causes clinical manifestations associated with ehrlichiosis. Ticks Tick Borne Dis. 5, 537-544.

Barrantes-González, A., Jiménez-Rocha, A., Romero-Zuñiga, J.J., Dolz, G., 2016. Serology, molecula detection and risk factors of Ehrlichia canis infection in dogs in Costa Rica. Ticks Tick Borne Dis., http://dx.doi.org/10.1016/j.ttbdis.2016.07. 006 (in press).

Breitschwerdt, E.B., Hegarty, B.C., Hancock, S.J., 1998. Sequential evaluation of dogs naturally infected with Ehrlichia canis, Ehrlichia chaffeensis, Ehrlichia equi, Ehrlichia ewingii, or Bartonella vinsonii. J. Clin. Microbiol. 36, 2645-2651.

Brenes, D., Brenes, S., Quirós, I., 2011. Ehrlichiosis: report of 2 cases. Revista AMC Costa Rica 53, 315-318.

Campos-Calderón, L., Ábrego-Sánchez, L., Solórzano-Morales, A., Alberti, A., Tore, G., Zobba, R., Jiménez-Rocha, A., Dolz, G., 2016. Molecular detection and identification of Rickettsiales pathogens in dog ticks from Costa Rica. Ticks Tick Borne Dis., http://dx.doi.org/10.1016/j.ttbdis.2016.07.015 (in press).

Chapman, A.S., Bakken, J.S., Folk, S.M., Paddock, C.D., Bloch, K.C., Krusell, A., Sexton, D.J., Buckingham, S.C., Marshall, G.S., Storch, G.A., Dasch, G.A., McQuiston, J.H., 
Swerdlow, D.L., Dumler, S.J., Nicholson, W.L., Walker, D.H., Eremeeva, M.E., Ohl, C.A., 2006. Diagnosis and management of tickborne rickettsial diseases rocky mountain spotted fever, ehrlichioses, and anaplasmosis - United States. a practical guide for physicians and other health-Care and public health professionals. MMWR Recomm. Rep. 55, 1-27.

Dantas-Torres, F., Figueredo, L.A., Brandao Filho, S.P., 2005. Primeira descrição de arasitismo humano por Rhipicephalus sanguineus (Acari: ixodidae) no Brasil. [First description of human parasitism by Rhipicephalus sanguineus (Acari: ixodidae) in Brazil]. Revista Soc. Brasileira de Med. Trop. 38, 411-412.

Dantas-Torres, F., Figueredo, L.A., Brandao Filho, S.P., 2006. Rhipicephalus sanguineus (Acari: ixodidae), the brown dog tick, parasitizing humans in Brazil [Rhipicephalus sanguineus (Acari: ixodidae), the brown dog tick, parasitizing humans in Brazil]. Revista Soc. Brasileira Med. Trop. 39, 64-67.

Dawson, J.E., Anderson, B.E., Fishbein, D.B., Sanchez, J.L., Goldsmith, C.S., Wilson, K.H., 1991. Isolation and characterization of an Ehrlichia sp: from a patient diagnosed with human ehrlichiosis. J. Clin. Microbiol. 29, 2741-2745.

Dawson, J.E., Candal, F.J., George, V.G., Ades, E.W., 1993. Human endothelial cells as an alternative to DH82 cells for isolation of Ehrlichia chaffeensis, E. canis and Rickettsia rickettsii. Pathobiology 61, 293-296.

Diniz, P.P., Schwartz, D.S., de Morais, H.S., Breitschwerdt, E.B., 2007. Surveillance for zoonotic vector-borne infections using sick dogs from southeastern Brazil. Vector Borne Zoonotic Dis. 7, 689-697.

Dolz, G., Jiménez Soto, M., Jiménez Rocha, A.E., Alberti, A., Zobba, R., Campos Calderon, L., Castro, R., Di Mare Hering, M.I., 2015. Ehrlichia spp. y Anaplasma spp. en mamíferos silvestres de áreas protegidas y áreas urbanas de Costa Rica [Ehrlichia spp. and Anaplasma spp. in wild mammals of protected areas and urban areas in Costa Rica in wild mammals of protected and urban areas of Costa Rica] V Congreso Latinoamericano de Enfermedades Rickettsiales. Revista Biomédica Mexico 26 (Suppl. 1), 79-80.

Doyle, C.K., Labruna, M.B., Breitschwerdt, E.B., Tang, Y.W., Corstvet, R.E., Hegarty, B.C., Bloch, K.C., Li, P., Walker, D.H., McBride, J.W., 2005. Detection of medically important Ehrlichia by quantitative multicolor TaqMan real-time polymerase chain reaction of the $d s b$ gene. J. Mol. Diagn. 7, 504-510.

Dumler, S.J., Barbet, A.F., Bekker, C.P.J., Dash, G.A., Palmer, G.H., Ray, S.C., Rikihisa, Y., Rurangirwa, F.R., 2001. Reorganization of genera in the families Rickettsiaceae and Anaplasmataceae in the order Rickettsiales: unification of some species of Ehrlichia with Anaplasma Cowdria with Ehrlichia and Ehrlichia with Neorickettsia, descriptions of six new species combinations and designation of Ehrlichia equi and HE agent as subjective synonyms of Ehrlichia phagocytophila. Int. J. Syst. Evol. Microbiol. 51, 2145-2165.

Dumler, J.S., 2005. Anaplasma and Ehrlichia infection. Ann. N. Y. Acad. Sci. 1063, 361-373.

Felek, S., Unver, A., Stich, R.W., Rikihisa, Y., 2001. Sensitive detection of Ehrlichia chaffeensis in cell culture, blood and tick specimens by reverse transcription-PCR. J. Clin. Microbiol. 39, 460-463.

Goddard, J., 1989. Focus of human parasitism by the brown dog tick, Rhipicephalus sanguineus (Acari: ixodidae). J. Med. Entomol. 26, 628-629.

Guglielmone, A.A., Beati, L., Barros-Battesti, D.M., Labruna, M.B., Nava, S., Venzal, J.M., Mangold, A.J., Szabó, M.J.P., Martins, J.R., González Acuña, D., Estrada-Peña, A., 2006. Ticks (Ixodidae) on humans in south america. Exp. Appl. Acarol. 40, 83-100

Gusa, A., Buller, R., Storch, G., Huycke, M., Machado, L., Slater, L., 2001. Identification of a p28 gene in Ehrlichia ewingii: evaluation of gene for use as a target for a species-specific PCR diagnostic assay. J. Clin. Microbiol. 39, 3871-3876.

Hall, T.A., 1999. BioEdit: to user-friendly biological sequence alignment editor and analysis program for Windows 95/98/NT. Nucleic Acids Symp. Ser. 41, 95-98.
Hernández de Mezerville, V., Padilla-Cuadra, J., 2007. Choque séptico por ehrlichiosis [Septic shock caused by ehrlichiosis]. Revista AMC Costa Rica 49, 118-120.

Ismail, N., Bloch, K.C., McBride, J.W., 2010. Human ehrlichiosis and anaplasmosis. Clin. Lab. Med. 30, 261-292.

Meneses, A., 1995. First report of canine ehrlichiosis in Costa Rica. Vet. Record 137, 46-47.

Miller, S.A., Dikes, D.D., Polesky, H.F., 1998. Simple and rapid method for DNA preparation with blood cells. Nuc. Ac. Res. 16, 1215.

Ndip, L.M., Ndip, R.N., Esemu, S.N., Dickmu, V.L., Fokam, E.B., Walker, D.H., McBride, J.W., 2005. Ehrlichial infection in Cameroonian canines by Ehrlichia canis and Ehrlichia ewingii. Vet. Microbiol. 111, 59-66.

Nicholson, W.L., Allen, K.E., Mc Quiston, J.H., Breitschwerdt, E.B., Little, S.E., 2010. The increasing recognition of rickettsial pathogens in dogs and people. Trends Parasitol. 26, 205-212

Perez, M., Rikihisa, Y., Wen, B., 1996. Ehrlichia canis-like agent isolated from a man in Venezuela: antigenic and genetic characterization. J. Clin. Microbiol. 34, 2133-2139.

Pérez, M., Bador, M., Zhang, C., Xiong, Q., Rikihisa, Y., 2006. Human infection with Ehrlichia canis accompanied by clinical signs in Venezuela. Ann. N. Y. Acad. Sci. 1078, 110-117.

Rojas, A., Rojas, D., Montenegro, V.M., Gutiérrez, R., Yasur-Landau, D., Baneth, G., 2014. Vector-borne pathogens in dogs from Costa Rica: first molecular description of Babesia vogeli and Hepatozoon canis infections with a high prevalence of monocytic ehrlichiosis and the manifestations of co-infection. Vet. Parasitol. 199, 121-128.

Rojas, N., Castillo, D., Marín, P., 2015. Molecular detection of Ehrlichia chaffeensis in humans, Costa Rica. Emerg. Infect. Dis. 21, 532-534.

Rojas-Solano, J.R., Villalobos-Vindas, J., 2007. Ehrliquiosis granulocitotrópica humana [Human granulocytotropic ehrlichiosis]. Revista AMC Costa Rica 49, $121-123$.

Romero, L.E., Dolz, G., Romero, J.J., Meneses, A., Jiménez, M., Salazar, L., 2010. Evaluacién del diagnéstico de Ehrlichia canis mediante frotis sanguóneo y tícnica molecular en perros de Costa Rica (Evaluation of the diagnosis of Ehrlichia canis through blood smear and molecular technique in dogs in Costa Rica). Ciencias Vet. Costa Rica 28, 23-36.

Romero, L.E., Meneses, A.I., Salazar, L., Jiménez, M., Romero, J.J., Aguiar, D.M., Labruna, M.B., Dolz, G., 2011. First isolation and molecular characterization of Ehrlichia canis in Costa Rica, Central America. Res. Vet. Sci. 91, 95-97.

Serra-Freire, N.M., Mendes de Sena, L.M., Pais Borsoi, A.B., 2011. Parasitismo humano por carrapatos na mata atlântica, rio de janeiro, brasil [Human parasitism by ticks in the atlantic forest, Rio de Janeiro, Brasil]. Entomo Brasilis 4, 67-72.

Silva, A.B., Pina, S., Gabriel de la Torre, M., Mayoral, A., Mayoral, M.A., Pérez-Campos, L., López, J., Pérez-Campos, E., 2014. Infeccién humana asintomótica por contacto con perros. Un caso de ehrlichiosis humana. [Asymptomatic human infection from contact with dogs. A case of human ehrlichiosis]. Gaceta Méd. México 150, 171-174.

Sirigireddy, K.R., Ganta, R.R., 2005. Multiplex detection of Ehrlichia and Anaplasma species pathogens in peripheral blood by real-time reverse transcriptase polymerase chain reaction. J. Mol. Diagn. 7, 308-316.

Tamura, K., Peterson, D., Peterson, N., Stecher, G., Nei, M., Kumar, S., 2011. MEGA5: molecular evolutionary genetics analysis using maximum likelihood, evolutionary distance, and maximum parsimony methods. Mol. Biol. Evol. 28 2731-2739. 